\title{
PERANAN ORANGTUA SEBAGAI WALI, PEMBIMBING, DAN PENDIDIK PADA PERKEMBANGAN ANAK DALAM PERSPEKTIF PENDIDIKAN AGAMA ISLAM
}

\author{
H. Moh. Rifai *
}

\begin{abstract}
Family, parents, wives, children, are an entity of a small social unit of mankind. Family is an inherent and natural social body which willingly or reluctantly will occur among moslem families. Parents' roles as the educator, guide of the children and family in order that they grow up to become ultimate moslems in the sense of insan kamil.
\end{abstract}

Key words: Parents, Educator, Advisor, Adult, Ultimate

\begin{abstract}
Abstrak
Keluarga atau rumah tangga, orangtua, suami, istri, dan anak adalah wujud kehidupan sosial unit kehidupan manusia yang kecil. Keluarga merupakan lembaga kehidupan yang asasi dan alamiah yang pasti secara islamiyah dialami oleh kehidupan keluarga muslim. Peran orangtua secara kodratnya sebagai pendidik, pembimbing dan pendamping istri, anak dan keluarga agar supaya anak tumbuh menjadi intelektual muslim sempurna lahir batin dalam arti kata insan kamil.
\end{abstract}

Kata kunci: Orangtua, Pendidik, Pembimbing, Dewasa, Sempurna

* H. Moh. Rifai adalah Dosen PGSD IKIP PGRI Madiun dan Kandidat Doktor Universitas Merdeka Malang

\section{A. Pendahuluan}

Menurut Undang-undang Nomor 1 Tahun 1994 (atau lazim disebut undangundang perkawinan) dalam Bab 1 Pasal 1 dijelaskan bahwa perkawinan ialah ikatan lahir dan batin antara seorang pria dan wanita sebagai suami istri dengan tujuan untuk membentuk keluarga (rumah tangga) yang bahagia dan kekal berdasarkan Ketuhanan Yang Maha Esa. Seleksi dan rencana perkawinan yang dibuat dengan pikiran yang matang, kecermatan akan memberikan kepuasan dalam rumah tangga (perkawinan). Perjalanan hidup suami istri akan diliputi oleh suasana penuh kebahagiaan. Bagaimanapun Islam telah memberikan aturan yang sangat baik buat pasangan suami istri, baik dalam Al Quran maupun Al Hadist. Tuntunan tentang kebaikan dan persamaan, kesabaran, dan cinta kasih, simpati, tenggang rasa, serta kemauan yang baik. Rasulullah pernah menyatakan: sebaikbaik muslim adalah yang paling baik terhadap keluarganya dan yang paling besar dan agung adalah istri yang baik, kepuasan dihasilkan dalam perkawinan itu 
terletak pada kedua belah pihak masing-masing baik istri maupun suami mempunyai hak dan kewajiban yang sama.

Peranan suami adalah mengembangkan ketentuan-ketentuan moral dan membimbing keluarganya sebagaimana yang telah ditentukan Allah. Ia menggauli istrinya dengan baik sebagaimana ia pertama kali mengawininya dan jika perkawinan tidak bisa diteruskan lagi. Iapun diperbolehkan menceraikan istrinya dan baik pula seorang suami tidak boleh menyakiti istrinya dan cara apapun suami istri mempunyai hak dan kewajiban yang sama namun suami dalam Islam lebih tinggi derajatnya daripada istri. Hal ini karena menurut pandangan Islam suami merupakan kepala keluarga, pemimpin keluarga berkewajiban harus melindungi istri dan anggota keluarganya. Itu adalah ketentuan Allah (agama).

\section{B. Pembahasan}

\section{Memelihara dan Membina Keluarga}

Tuntutan agama dapat menjadi pelita yang dapat menerangi hati suami istri agar lebih gesit dalam mengusahakan ketenangan dalam rumah tangganya. Agama juga dapat menjadi pendorong semangat dalam melaksanakan kewajiban masingmasing yang dapat mencegah keruntuhan rumah tangga. Keputusan terhadap agama dapat berfungsi sebagai pupuk yang menyuburkan perasaan cinta dan kasih sayang diantara mereka. Atas dasar pernikahan atau perkawinan maka terbentuklah keluarga kecil, untuk itu demi terwujudnya keluarga yang bahagia dan sejahtera maka harus ada pembinaan dan pemeliharaan ini tentu menyangkut tugas dan tanggung jawab suami, istri maupun anak-anaknya, karena fungsi tugas tanggung jawab inilah terjadi proses interaksi yang dapat melahirkan suasana saling mengerti, menyadari akan terwujudnya keluarga bahagia dan sejahtera.

Suami istri dalam kehidupan berumah tangga sehari-hari, mempunyai fungsi sendiri-sendiri yang harus dilaksanakan semaksimal mungkin dengan penuh kesadaran sebab setiap laki-laki dan perempuan yang telah memasuki jenjang perkawinan dalam rumah tangganya mempunyai fungsi masing-masing, mempunyai kewajiban yang berbeda. Hasan menjelaskan tugas dan kewajiban seorang suami merupakan ketetapan yang tidak dapat ditawar, bahwa pria ditunjuk untuk menjadi pemimpin kaum wanita. Bapak adalah pemimpin keluarga, istri, anak-anak dan anggota keluarga pada umumnya. Hubungan suami istri di dalam keluarga atau di dalam rumah tangga adalah sangat erat dan terusmenerus. Namun perlu diingat bahwa kehidupan tersebut dibina oleh dua insan yang berbeda yang mana keduanya terdapat perbedaan sifat dan sikap kepribadian masing-masing. Oleh karena itu keduanya harus saling pengertian dalam melaksanakan hak dan kewajibannya. Sebab pada hakikatnya mereka itu mempunyai tujuan yang sama yaitu ingin merasakan ketenangan dan kebahagiaan hidup bersama.

Memahami hak dan kewajiban masing-masing. Dalam kehidupan bersama, mutlak dibutuhkan adanya hak dan kewajiban. Selama orang didalamnya tetap menghayati dan menghormati aturan tersebut, dapat dipastikan bahwa kehidupan secara bersama itu dapat saling melengkapi untuk bersama-sama melaksanakan tujuan yang telah ditetapkan. Maka untuk mencapai tujuan itu masing-masing anggota keluarga bersedia secara sadar untuk menunaikan kewajibannya, sehingga 
mereka akan memberikan hak kepada anggota keluarga lainnya. Pemeliharaan dan pendidikan agama anak. Sebagaimana kita ketahui bersama bahwa anak adalah sangat menyenangkan, tetapi sekaligus merupakan ujian bagi orangtua. Sebagai ujian tentu ada dua kemungkinan yang jika lulus pasti membahagiakan dan jika gagal pasti mengecewakan. Demikian pula halnya dengan anak, apabila orangtua berhasil mendidik dan membina anak-anaknya sebagai amanat Allah maka dijanjikan suatu imbalan berupa kebahagiaan dan kesenangan dunia sampai akherat. Hasan menyatakan pendapatnya tentang pendidikan anak sebagai berikut: Jelaskan sekarang anak yang dididik dengan baik sehingga menjadi anak yang sholeh, tidak hanya memberi kesenangan dan keberuntungan kepada kedua orangtuanya meninggal pun masih dapat merasakan pahala dan syaratnya dari doa anaknya. Untuk itulah upaya mengusahakan sungguhsungguh agar anaknya menjadi anak yang baik, terpelihara dari segala perbuatan yang dimurkai Allah dan tekun mematuhi perintah agama.

Bagaimanapun juga penghayatan dan pengamalan ajaran agama sangat membantu anggota keluarga di dalam mewujudkan dan memelihara kebahagiaan pada rumah tangga. Dan apabila kepala keluarga beserta seluruh anggota keluarga telah memiliki pengetahuan fungsional agamanya, yang mana bukan hanya sekedar menghafal dengan luar kepala tentang aturan-aturan yang ada dalam AlQuran dan Al-Hadist melainkan benar-benar mewarnai situasi kehidupan di dalam rumah tangganya. Maka melihat betapa pentingnya pengetahuan agama bagi seseorang yang menginginkan keluarganya aman tenteram dan damai, untuk itu kesemuanya itu tidak lepas dari kesadaran dan jiwa Islam yang harus mendalam pada tiap-tiap anggota keluarganya.

Demikianlah cara-cara pembinaan keluarga muslim yang harus dilakukan dengan sebaik-baiknya agar semua anggota keluarga menghayati dan mengamalkan ajaran agama demi tercapainya keluarga yang sakinah sesuai dengan kehidupan rumah tangga yang berlandaskan Islam. Maka suami sebagai to manager di rumah tangga menyadari statusnya sebagai pemimpin yang harus bertanggung jawab atas kelangsungan hidup keluarganya, yang berlandaskan ajaran agama dari tuntunan Al-Quran yang merupakan sumber dari segala sumber hukum dan juga Al-Hadist yang juga menentukan baik buruk atau bahagianya keluarga muslim. Keluarga Sejahtera Menurut Konsepsi Islam. Untuk menggambarkan tentang keluarga yang sejahtera memerlukan pengkajian yang sangat luas dimana arti sejahtera itu sendiri relatif tergantung pada maksud yang berlaku pada mulanya. Kebahagiaan dan ketentraman hidup berumah tangga itu berarti terwujudnya suatu kesejahteraan hidup lahir batin, jasmaniyah dan rohaniyah. Sejahtera lahir berarti terwujudnya segala kubutuhan yang bersifat materiil sebagai limpahan dan karunia nikmat dari Allah yang berupa kebendaan. Sedangkan sejahtera batin adalah timbulnya suatu ketenangan dan ketentraman jiwa dari limpahan rahmat dan hidayah Allah yang menjadi sumber keabadian manusia. Jadi yang dimaksud keluarga sejahtera disini adalah kelurga yang didalamnya terdapat rasa aman dan tenteram dan terpenuhinya kebutuhan lahiriyah serta batiniyah dan segala bentuk amal perbuatannya didasarkan pada ajaran Islam. 
Di atas disebutkan bahwa keluarga yang sejahtera adalah keluarga yang terpenuhi segala kebutuhan hidup. Hubungan baik antar anggota keluarga merupakan azas dasar dalam membentuk rumah tangga yang islami. Menurut ajaran Islam perkawinan bukan semata-mata untuk mencapai kemaslahatan yang bersifat material saja, tetapi merupakan ikatan yang suci sebagai pelaksana perintah Allah. Yaljan menyatakan hubungan baik antaranggota keluarga merupakan faktor yang sangat menentukan bagi kebutuhan rumah tangga. Islam adalah agama yang mengajarkan agar selalu hidup bersama dengan suka tolong menolong antar sesamanya. Dalam buku Pendidikan Agama Islam diuraikan bahwa seorang muslim yang baik ialah akan berbuat baik dalam kehidupan bermasyarakat maupun bertetangga. Karena hanya berbuat baik itulah lahir kasih sayang menyayangi dan kehidupan yang rukun.

Kebutuhan adalah keinginan manusia terhadap barang atau benda dan jasa didalam memenuhi dan mempertahankan hidupnya yang pemuasnya bisa dilakukan baik bersifat jasmani maupun rohani. Dan kebutuhan ini timbul karena adanya tuntutan fisik atau rohani manusia agar hidup layak sebagai manusia didalam lingkungannya. Diuraikan di dalam buku Ekonomi Koperasi tentang jenis kebutuhan ditinjau dari bentuk dan sifatnya adalah: (1) kebutuhan jasmani atau material, yaitu kebutuhan yang diperlukan oleh fisik manusia atas barang dan jasa. Contoh: makan, minum, pakaian, dan kesehatan; dan (2) kebutuhan rohani atau spiritual, yakni kebutuhan yang diperlukan tidak secara fisik, yang bisa terpenuhi akan menimbulkan kepuasan batin dari orang tersebut. Contoh: rekreasi, musik, dan pendidikan. Dengan terbentuknya keluarga kecil, dapatlah dipahami bahwasanya pria dan wanita yang saling membutuhkan akan mendapat kesempatan merasakan kebahagiaan lahir batin.

Jika ditelaah maka keadaan dalam suatu keluarga bahagia hal ini memang mungkin sekali sebab diantara mereka akan saling melindungi bila datang suatu cobaan hidup dan saling bantu bila datang suatu kesulitan dalam kehidupan sehari-hari. Kesemuanya diatas harus didasarkan pada ajaran agama Islam, karena bagaimanapun juga agama Islam sangat membantu usaha anggota keluarga dalam mewujudkan dan memelihara kesejahteraan dan kebahagiaan hidup berumah tangga yang Islami. Mengapa demikian? Jawablah adalah karena aturan agama itu ditetapkan oleh Allah SWT Dzat Yang Maha Kuasa dan Mengetahui, pencipta alam semesta termasuk manusia itu sendiri. Aturan tentang sesuatu yang ditetapkan oleh yang menciptakannya pasti akan lebih berhasil guna, daripada dibuat oleh selain yang menciptakannya pasti akan lebih berhasil guna, daripada dibuat oleh selain yang menciptakannya. Demikian aturan berumah tangga jika seluruh anggota menghayati dan mengamalkan ajaran agamanya pasti akan terbuka lebar kebahagiaan, kesejahteraan dan ketentraman di dalamnya sebab manusia yang membina keluarga juga ciptaan Allah SWT sedangkan kebahagiaan pada hakikatnya juga merupakan pemberian Allah.

\section{Peranan Orangtua sebagai Pendidik dalam Keluarga Muslim}

Kehidupan di dalam rumah tangga atau dalam keluarga tidak lepas dari tugas dan tanggung jawab dari tiap-tiap anggota keluarga itu. Dalam hal ini orangtua memegang peranan paling penting demi tercapainya keluarga yang 
aman, damai, dan sejahtera. Rumah tangga dapat diibaratkan seperti bahtera, yang sedang berlayar di lautan yang tentunya tidak mustahil bila ditimpa dengan cobaan-cobaan, yang terkadang sulit dipecahkan. Maka dari itu tugas inilah yang harus dipikul bersama-sama mengemban tanggung jawab dan tugas yang berat tapi mulia itu.

Begitu pula selanjutnya tugas orangtua terhadap anak-anaknya adalah memberi pendidikan dan pembinaan terutama pendidikan yang sifatnya membentuk kepribadian anak yang akan menjadi bekal hidup selanjutnya. Dalam pendidikan keluarga ini orangtualah yang mempunyai peranan yang sangat penting. Orangtua sebagai pemelihara, pelindung, serta perkembangan anak selanjutnya. Maka peranan orangtua sebagai pendidik dalam keluarga muslim itu diantaranya: meluruskan fitroh Islam setiap anak yang dibawa sejak lahir. Karena menurut ajaran Islam setiap anak yang dilahirkan telah mempunyai kecenderungan atau pembawaan untuk beragama yang dikenal dengan istilah fitroh. Seperti disebutkan dalam Al-Quran surat Ar-Rum ayat 30 yang artinya: "Maka hadapkanlah wajahmu dengan lurus kepada agama Allah, (tetaplah atas) fitroh Allah yang telah menciptakan manusia menurut fitroh itu". Kemudian tentang fitroh itu tidak akan berjalan ke arah yang lurus tanpa diarahkan dan bimbingan oleh orang lain. Sebagaimana dijelaskan dalam hadist Nabi: "Setiap anak yang dilahirkan telah membawa fitroh sehingga fasih lidahnya, maka orangtuanyalah yang menjadikan anak tersebut yahudi, nasroni atau majusi".

Dari hadist tersebut diatas menunjukkan bahwa fitroh Islam yang dibawa anak itu tidak bisa berjalan dengan lancar tanpa adanya pendidikan, bimbingan dan pembinaan dari orangtua, oleh karena itu tugas orangtua mengarahkan dan meluruskan serta mendampingi sehingga anak tumbuh dewasa dengan sempurna. Suasana keagamaan maksudnya adalah menjadikan rumah tangga itu menjalani kehidupan sehari-hari selalu didasarkan atas perintah-perintah dan ajaran Islam, beramal, bertingkah laku maupun kegiatan lainnya selalu diwarnai oleh ajaran Islam. Untuk mencapai tujuan itu semua harus diberikan pendidikan yang bersifat Islam baik itu membimbing, membina dan memelihara anak agar anak-anak itu bisa selamat. Menurut ajaran Islam pembinaan yang diberikan kepada anak bukan hanya berdasar kepentingan keduniaan semata, tetapi akherat juga harus diutamakan. Untuk mencapai suasana keagamaan anak harus diberi bimbingan juga. Pendidikan agama yang bertujuan mencetak anak-anak mau memahami dan mengamalkan ajaran agamanya. Mereka dibimbing untuk menjadi manusia yang cerdas dan bertaqwa kepada Allah SWT dan memiliki perilaku dan budi pekerti yang luhur serta perangai yang mulia.

Perlu diingat bagi orangtua bahwa sebaiknya semua tingkah laku yang baik harus diberikan lewat perbuatan yang kongkrit dan dalam beramal lewat keteladanan, sebab pemberian contoh iu lebih efektif dibandingkan lewat perintah suruhan. Demikian selanjutnya bila semua anggota rumah tangga menghayati dan mengamalkan ajaran agamanya pasti akan terbuka lebar kebahagiaan dan kesejahteraan seluruh anggota keluarga itu dan semuanya saling menyayangi antara anggota keluarga. Sabda Nabi Muhammad SAW: "Apabila Allah itu menghendaki anggota rumah tangga itu tenang dan sejahtera, maka Allah memberikan kasih sayang diantara mereka". 
Orangtua atau suami wajib mencukupi nafkah keluarganya dengan rizki yang halal. Tugas ini termasuk fungsi suami dalam rumah tangga yakni memenuhi segala kebutuhan anggota keluarga dari rizki yang halal. Masalah nafkah rumah tangga merupakan hal sangat penting. Karena akan berpengaruh atas kekokohan dan kelangsungan rumah tangga. Oleh karena itu perlu adanya pengaturan dengan sebaik-baiknya, darimana sumbernya dan bagaimana penggunaannya, harus dipikirkan oleh suami semampunya. Firman Allah dalam Al-Quran surat AtThalaaq ayat 7 yang artinya: "Hendaklah orang yang mampu memberikan nafkah menurut kemampuannya. Dan orang yang disempitkan rizkinya hendaklah memberikan nafkah dari harta yang diberikan Allah kepadanya".

Orangtua berkewajiban menjaga keselamatan anak-anak dan anggota keluarga lainnya baik lahir maupun batin terutama pengalaman agama. Dalam tugas ini orangtua berkewajiban memelihara keselamatan anggota keluarganya baik di dunia maupun diakherat kelak. Dijelaskan dalam Al-Quran surat AtTahrim ayat 6 yang artinya: "Hai orang-orang beriman peliharalah dirimu dan keluargamu dari api neraka”. Kalau diperhatikan ayat diatas jelaslah bahwa Allah SWT menetapkan adanya kewajiban orangtua terhadap keluarganya untuk memberikan bimbingan agama dengan penuh kesabaran agar menemukan keselamatan hidup baik didunia maupun di akherat kelak.

Dari beberapa uraian tersebut di atas dapat diambil pengertian bahwa orangtua sangat berperan dalam membina keluarga sakinah yang berlandaskan ajaran Islam dan pada hakikatnya kesejahteraan dan ketentraman dalam keluarga bukan harta benda yang melimpah, namun keluarga yang Islami yang sejahtera adalah terjadinya hubungan yang harmonis antara anggota keluarga dan saling menyadari akan tugas dan tanggung jawab masing-masing, serta rizqi yang cukup juga mendapat ridho Allah SWT. Yang semua itu dalam agama Islam sebagai rohmatan lil'alamin. Maka dari itu penjelasan di atas dapat diambil kesimpulan bahwa kebahagiaan dan kesejahteraan keluarga terletak pada peranan suami istri atau yang disebut dengan orangtua karena merekalah yang menjadi pemeran utama dalam keluarga. Kebijaksanaan dan kearifan serta kehalusan orangtua akan dapat membangun taman kehidupan rumah tangga yang menyejukkan hati serta akan terciptalah keluarga yang bahagia dan sejahtera lahir dan batin yang mendapatkan ridho dari Allah SWT.

\section{Lampu Kuning Buat Orangtua}

Sebagaimana kita ketahui bahwa kemajuan teknologi dari waktu ke waktu semakin kompetitif dan akan melindas siapapun dari makhluk Tuhan yang namanya manusia tidak terkecuali di belahan dunia manapun. Manusia itu hidup dan berada mulai dari yang status ekonominya - berkelas - elite dan atau kelas ekonomi menengah atau bahkan ekonomi yang paling rendah pun bahkan tidak pandang status yang ia sandang, mulai juragan (majikan), sehingga kaum pekerja dan bahkan dari kelompok pembantu rumah tangga, sehingga dengan itu semua akan merasakan betapa ketatnya persaingan hidup dan bahkan kejamnya kehidupan. Sehingga dengan itu menciptakan tradisi baru yang antaranya manusia sudah mulai berkurang rasa kepeduliannya dengan orang lain bahkan orangtua terhadap anaknya atau sebaliknya anak terhadap orangtuanya, dan yang paling 
mengerikan bahwa semuanya diukur dengan materi/uang, kecenderungan ke arah kedekatan hati antarkeduanya mulai berkurang.

Semua dihitung dengan cost (uang) yang harus dikeluarkan. Ini adalah hasil dari survei sosial yang ada. Yang lebih parah lagi persoalan perhatian orangtua terhadap prilaku anak-anak yang masih dalam taraf wajar (9 tahun) wajib belajar 9 tahun atau biasa disebut periode pertama dalam istilah Abdullah Al Audah, dalam Tarbiyatul Aulad Fil Islam, Al Markhalatul awal. Pada anak yang baru berusia antara 4 tahun sehingga berumur 13 tahun. Usia yang sangat rentan dengan stimulus (pengaruh) dari luar yang ia biasa melihat dan mendengar, hampir semua akan ditiru atau diikutinya. Sebagaimana hasil dari penelitian di berberapa kecamatan yang telah penulis lakukan seperti dalam tabel di bawah ini.

Tabel 1 Penggunaan Internet dari Setiap Wilayah

\begin{tabular}{lll}
\hline \multicolumn{1}{c}{ Kecamatan } & \multicolumn{1}{c}{ Kabupaten } & \multicolumn{1}{c}{ Pengguna internet } \\
\hline Kec. Taman & Madiun Kota & \pm 30 warnet : @ 20-30 orang \\
Kec. Bangilan & Tuban & \pm 50 warnet : @ 20-30 orang \\
Kec. Jiwan & Madiun & \pm 25 warnet : @ 20-30 orang \\
Kec. Nganjuk & Nganjuk & \pm 23 warnet : @ 20-30 orang \\
Kec. Snori & Tuban & \pm 21 warnet : @ 20-30 orang \\
Kec. Tarokan & Kediri & \pm 28 warnet : @ 20-30 orang \\
\hline
\end{tabular}

Tabel 2 Sebaran Penggunaan Berdasarkan Jenjang Pendidikan

\begin{tabular}{cccccc}
\hline \multicolumn{2}{c}{ Pelajaran Tk. SD } & \multicolumn{2}{c}{ Pelajar Tk. SMP } & \multicolumn{2}{c}{ Pelajar Tk. SMU } \\
\hline P & L & P & L & P & L \\
\hline $78 /$ & $61 /$ & $72 /$ & $63 / 100 \%$ & $52 / 100 \%$ & $65 /$ \\
$100 \%$ & $100 \%$ & $100 \%$ & & & $100 \%$ \\
Game & $\begin{array}{c}\text { Game } \\
\text { online }\end{array}$ & Facebook & $\begin{array}{c}\text { Tugas / } \\
\text { facebook }\end{array}$ & $\begin{array}{c}\text { Facebook } \\
\text { / tugas }\end{array}$ & $\begin{array}{c}\text { Tugas / } \\
\text { facebook }\end{array}$ \\
\hline
\end{tabular}

Tabel 3 Sebaran tentang Pemberitahuan Orangtua

\begin{tabular}{cc}
\hline Pemberitahuan orangtua*) & Keterangan \\
\hline Ya & $93 \%$ \\
Tidak & $7 \%$ \\
\hline
\end{tabular}

Tabel 4 Sebaran tentang Kepedulian Orangtua

\begin{tabular}{cc} 
Kepedulian orangtua**) & Keterangan \\
\hline Ya & $7 \%$ \\
Tidak & $93 \%$ \\
\hline
\end{tabular}

*) Keterangan pemberitahuan orangtua (minta uang internet)

**) Kroscek orangtua terhadap perilaku anak di internet

Berdasarkan tabel di atas menunjukkan bahwa apa yang dikerjakan anak pada usia wajar 9 tahun (usia 6 s.d. 13 tahun) ternyata lebih dominan melakukan game online, daripada melakukan pekerjaan rumah yang diwajibkan dari sekolah. Dari tingkat SMP s.d. SMA mayoritas yang dilakukan di internet bermain facebook dengan member-nya dibanding dengan melakukan tugas sekolah. 


\section{Pengenalan Karakteristik Siswa Sekolah Dasar}

Mengenal karakteristik peserta didik untuk kepentingan proses pembelajaran merupakan hal yang penting. Adanya pemahaman yang jelas tentang karakteristik peserta didik akan memberikan kontribusi terhadap pencapaian tujuan pembelajaran secara efektif. Berdasarkan pemahaman yang jelas tentang karakteristik peserta didik, para guru dapat merancang dan melaksanakan kegiatan pembelajaran sesuai perkembangan anak. Menurut Mushtafa (2002) praktik pendidikan dan pengajaran anak usia dini selama beberapa dasawarsa belakangan ini sangat dipengaruhi oleh teori perkembangan Jean Piaget. Piaget mengkategorikan empat tahapan perkembangan kognitif dan afektif yang dilalui manusia. Menurut teori ini, anak-anak berkembang secara kognitif melalui keterlibatan aktif dengan lingkungannya. Dikaitkan dengan teori ini, perkembangan anak usia dini berada pada tahap berpikir praoperasional (usia 2 s.d. 7 tahun). Pada tahap ini perkembangan anak sudah ditandai dengan perkembangan bahasa dan berbagai bentuk representasi lainnya serta perkembangan konseptual yang pesat. Proses berfikir anak berpusat pada penguasaan simbol-simbol seperti kata-kata yang mampu mengungkapkan pengalaman masa lalu.

Manipulasi simbol termasuk kata-kata merupakan karakteristik penting dari tahap praoperasional. Hal ini tampak dalam meniru sesuatu yang tertunda sehingga menghasilkan suatu tindakan yang telah dilihat di masa lalu dan dalam imajinasi anak-anak atau pura-pura bermain. Nalar anak-anak pada tahap ini belum tampak logis dan mereka cenderung sangat egosentris. Egosentris pada anak usia prasekolah tidak berarti ia mementingkan diri sendiri, melainkan anak usia prasekolah tidak dapat melihat sesuatu dari pandangan orang lain. Anak-a

usia 5 s.d. 7 tahun sebagai tahun-tahun awal memasuki sekolah dasar mereka mempunyai ciri-ciri sebagai berikut:

a. Kebanyakan anak-anak usia ini masih berada pada tahap berpikir praoperasional dan cocok belajar melalui pengalaman konkrit dan dengan orientasi tujuan sesaat;

b. Mereka suka menyebut nama-nama benda, mendefinisikan kata-kata, dan mempelajari benda-benda yang berada di lingkungan dunianya sebagai anakanak

c. Mereka belajar melalui bahasa lisan dan pada tahap ini bahasanya telah berkembang dengan pesat; dan pada tahap ini anak-anak sebagai pembelajar memerlukan struktur kegiatan yang jelas dan intruksi spesifik.

Furqon (2005: 35) mengungkapkan bahwa secara kronologis, siswa SD pada umumnya berusia antara 5 s.d. 13 tahun atau sampai tiba saatnya individu menjadi matang secara seksual. Pada masa ini anak mulai keluar dari lingkungan keluarga dan mulai memasuki lingkungan sekolah. Ada tiga ciri utama pada masa ini yang mampu menunjukkan perbedaan dengan masa sebelumnya, yaitu:

a. Dorongan anak untuk masuk ke dalam dunia permainan dan pekerjaan yang membutuhkan keterampilan otot-otot;

b. Dorongan anak untuk keluar dari lingkungan rumah dan masuk ke dalam kelompok sebaya (peer group); 
c. Dorongan mental untuk mematuhi dunia konsep-konsep logika, simbol dan komunikasi secara dewasa.

Havighurst mengemukakan sejumlah tugas perkembangan yang harus dipenuhi oleh anak usia 6 s.d. 13 tahun, yaitu:

a. Mempelajari keterampilan fisik yang diperlukan untuk bermain;

b. Membangun sikap yang sehat mengenai diri sendiri sebagai makhluk yang sedang tumbuh;

c. Belajar menyesuaikan diri dengan teman sebaya;

d. Mulai mengembangkan peran sosial sebagai laki-laki dan perempuan;

e. Mengembangkan ketrampilan-ketrampilan dasar untuk membaca, menulis dan berhitung;

f. Mengembangkan pengertian-pengertian yang diperlukan dalam kehidupan sehari-hari;

g. Mengembangkan kata hati, moral dan nilai-nilai;

h. Mengembangkan sikap terhadap kelompok-kelompok dan lembaga-lembaga sosial;

i. Mencapai kebebasan pribadi.

Pada masa anak sekolah, penguasaan tugas-tugas perkembangan tidak lagi sepenuhnya menjadi tanggung jawab orangtua seperti masa sebelum sekolah. Tetapi sekarang penguasaan ini pun menjadi tanggung jawab guru dan sebagian kecil menjadi tanggung jawab teman sebaya. Untuk lebih memperjelas mengenai tugas-tugas perkembangan yang dikemukakan Havighurst, dibawah ini dikemukakan beberapa aspek perkembangan psiko-fisik anak usia sekolah dasar, yaitu: (1) keadaan fisik dan ketrampilan; dan (2) setelah anak usia 6 tahun, pertumbuhan fisik menjadi agak lambat tetapi keseimbangan relatif berkembang baik. Anak mungkin dapat menjaga keseimbangan badannya, sehingga mereka senang berjalan di atas benteng, pagar, dan sebagainya.

Penguasaan badan seperti jongkok, melakukan latihan senam, serta berbagai aktifitas olahraga berkembang pada masa anak-anak sekolah. Pada masa ini berkembang pula koordinasi mata-tangan yang diperlukan untuk membidik, menendang, melempar dan menangkap. Hurlock mengemukakan empat kategori keterampilan yang dimiliki anak-anak pada usia sekolah, yaitu:

a. Keterampilan menolong diri sendiri, seperti makan, berpakaian, berdandan sendiri seperti orang dewasa;

b. Keterampilan menolong orang lain, seperti membantu merapikan tempat tidur, membantu membersihkan papan tulis, dan sebagainya;

c. Keterampilan sekolah, seperti keterampilan yang diperlukan untuk menulis, menggambar, membentuk, mewarnai, dan pekerjaan tangan yang menggunakan berbagai alat;

d. Keterampilan bermain, seperti keterampilan melempar dan menangkap bola, naik sepeda, atau berenang. 


\section{Kemampuan Bahasa}

Pada masa ini, kemampuan berbahasa merupakan salah satu sarana dalam memperluas lingkungan sosial anak. Karena meluasnya cakrawala sosial anak, anak akan menemukan bahwa bahasa atau berbicara merupakan sarana penting untuk memperoleh tempat dalam kelompok. Selain itu anak juga mengetahui bahwa komunikasi adalah kemampuan dirinya untuk mengerti apa yang dikatakan orang lain, tidak saja menyulitkan berkomunikasi dengan orang lain tetapi ia cenderung mengatakan sesuatu yang sama sekali tidak berhubungan dengan apa yang dibicarakan teman-temannya, sehingga ia tidak diterima oleh kelompoknya.

Pada masa ini pun anak sudah menggunakan kosakata rahasia dalam berkomunikasi dengan sahabatnya. Kata rahasia ini dapat berbentuk tulisan, terdiri dari kode-kode berbentuk lambing atau pengganti huruf; bentuk lisan dapat berupa kata-kata yang dirusak; atau bentuk kinetik yang terdiri dari isyarat dan penggunaan jari-jari untuk mengkomunikasikan kata-kata. Penggunaan kosakata rahasia dimulai saat anak memasuki kelas tiga dan mencapai puncaknya beberapa saat sebelum masa puber.

\section{Keadaan Emosi}

Pada masa ini anak sudah memiliki dorongan untuk mengendalikan emosinya. Melalui interaksi dengan kelompok sebaya anak memahami bahwa ledakan emosi yang kurang baik tidak dapat diterima teman-temannya. Pada umumnya keadaan emosi anak cenderung lebih tenang sampai datangnya masa puber. Ketenangan emosinya itu disebabkan beberapa hal, yaitu: (1) peranan yang harus dilakukan anak yang lebih besar sudah terumus secara jelas, dan anak sudah mengetahui bagaimana melaksanakannya; (2) permainan dan olahraga merupakan bentuk penyaluran emosi yang tertahan; dan (3) meningkatnya keterampilan anak yang diperlukan untuk menyelesaikan berbagai macam tugas.

\section{Sikap dan Perilaku Moral}

Disaat individu menyadari bahwa dirinya sebagai bagian dari suatu kelompok, maka saat itu pula ia mulai menyadari aturan perilaku boleh, harus, dan dilarang dilakukan dirinya dan kelompok itu. Dalam hal ini, Piaget mengemukakan bahwa pada masa ini anak mulai menggantikan moral yang kaku menjadi relativisme. Misalnya berbohong bagi anak yang berusia lima tahun selalu buruk, sedangkan bagi mereka yang lebih besar sadar bahwa dalam beberapa situasi, berbohong dibenarkan, karena berbohong tidak selalu buruk. Karena itu sekolah dituntut perhatian yang lebih besar, sehingga pendidikan mengenai benar dan salah seyogianya menekankan alasan mengapa perilaku tertentu diterima dan mengapa pola perilaku lainnya tidak diterima. Ini berarti bahwa pihak guru dan orangtua harus memperlakukan anak secara konsisten, sehingga setiap yang benar hari ini, besok juga benar dan lusa pun masih tetap benar. Perbuatan yang salah harus mendapatkan hukuman yang sama bila perbuatan itu setiap kali diulang, dan perbuatan yang benar harus mendapat ganjaran yang sama. 


\section{Perilaku Sosial Siswa Sekolah Dasar}

Perilaku sosial merupakan pola perilaku yang relative menetap, yang diperlihatkan individu dalam interaksinya dengan orang lain. Pada usia Sekolah Dasar, anak sering disebut sebagai usia berkelompok. Karena masa ini ditandai dengan meningkatnya minat anak terhadap aktivitas teman-teman, meningkatnya keinginan yang kuat untuk diterima sebagai anggota suatu kelompok, dan merasa tidak puas bila tidak bersama-sama dengan teman-temannya. Karena melalui kelompok itulah anak-anak akan memperoleh kegembiraan dan kepuasan dari permainan yang mereka lakukan. Lebih dari itu, melalui teman-teman dalam kelompoknyalah sebagian kecil tugas-tugas perkembangan yang diembannya akan terpenuhi.

Sejalan dengan meningkatnya minat untuk berkelompok, Erickson mengemukakan bahwa salah satu tugas utama yang harus dipenuhi anak sekolah dasar yaitu mencapai kesadaran akan kerajinan (sense of industry), dan kegagalan dalam mencapai kesempurnaan pengerjaannya akan mengakibatkan rasa rendah diri dan tidak mampu (sense of inferiority and sense inadequacy). Artinya bila anak mengalami kegagalan dalam menemukan dan mencapai yang bermanfaat secara pribadi, maka dia akan cenderung untuk tidak merasakan adanya kemampuan sebagai orang dewasa kelak dan tahap atau fase perkembangan selanjutnya akan terpengaruh secara tidak menguntungkan.

\section{Beberapa Masalah pada Siswa Sekolah Dasar}

Kowitz mengemukakan bahwa beberapa rintangan yang muncul di sekolah dasar pada umumnya disebabkan oleh karakteristik anak itu sendiri (Furqon, 2005: 44). Saat yang belum matang anak memasuki sekolah, keterampilan akademis yang belum merata untuk semua mata pelajaran dan bidang studi, kemampuan sosial yang kurang berkembang, penyesuaian pribadi yang negative, dan harapan-harapan orangtua, kelompok dan lembaga pendidikan itu sendiri terlalu tinggi, sehingga tidak realistis. Secara rinci, permasalahan yang dihadapi anak sekolah dasar adalah:

a. Masalah Pribadi

Permasalahan pribadi anak usia sekolah dasar terutama berkenaan dengan kemampuan intelektual, kondisi fisik, kesehatan dan kebiasaan-kebiasaannya. Di kelas satu atau kelas dua, tidak jarang ditemukan anak yang semestinya belajar pada sekolah luar biasa, tetapi mereka disertakan dan disejajarkan dengan siswa yang mempunyai kemampuan normal. Kejadian itu muncul sebagai akibat ketidakmampuan kita dalam mengidentifikasi kemampuan mereka sejak dini. Anak-anak yang memiliki kelemahan intelektual tergolong ringan, baru diketahui setelah menginjak kelas-kelas yang lebih tinggi.

Munculnya gejala perilaku malas untuk belajar, malas datang ke sekolah, bahkan sering mengakibatkan bertambahnya angka putus sekolah, merupakan akibat kurangnya pelayanan individual yang dilakukan oleh pihak sekolah yang didasarkan atas kemampuan intelektual anak. Kondisi psikis anak-anak secara relatif lebih sehat dibandingkan orang dewasa. Beberapa penyimpangan perilaku yang diderita anak seperti ketergantungan, kurang percaya diri, kurang memiliki inisiatif, kurang tanggung jawab, menunjukkan perilaku agresif, merupakan akibat 
perlakuan orangtua yang membentuk kebiasaan-kebiasaan yang tidak didasari pemikiran mengenai dampak perlakuannya.

b. Masalah Penyesuaian Sosial

Anak belajar bukan hanya dari seorang guru, tetapi juga dari temantemannya, dan bukan hanya kemampuan kognitif yang dipelajari namun termasuk kemampuan sosial pun dipelajarinya. Dalam mengembangkan kemampuan penyesuaian sosial, baik dengan teman-teman maupun dengan gru, anak-anak banyak mengalami permasalahan. Misalnya perasaan rendah diri, iri hati, cemburu, curiga, persaingan, dan perkelahian. Sedangkan permasalahan penyesuaian sosial anak dengan gurunya, misalnya anak tidak menyenangi guru, tidak ada semangat belajar atau masalah lain yang berhubungan dengan kedisiplinan.

Gejala perilaku tersebut muncul sebagai akibat adanya salah asuh dalam keluarga, perbedaan latar belakang ekonomi, sosial budaya keluarga, atau adanya penyimpangan kepribadian anak. Dari pihak sekolah mungkin permasalahan ini muncul sebagai akibat kesalahan atau kelemahan guru dalam memperlakukan anak, baik perlakuan pilih kasih, tidak konsisten, atau penampilan guru yang kadang-kadang kurang pada tempatnya.

\section{c. Masalah Akademik}

Masalah akademik bisa berupa tidak dikuasainya kemampuan atau materi yang ditargetkan sebagai tujuan pengajaran. Anak seperti ini sering dikenal sebagai anak yang berprestasi rendah, baik karena lambat belajar (slow learner) maupun prestasinya di bawah kemampuan yang dimilikinya (under achiever). Dengan demikian, ketidakberhasilan mereka dalam mencapai prestasi belajar yang tinggi bukan hanya disebabkan oleh kecerdasan saja, tetapi mungkin juga sebagai akibat dari kesalahan dalam cara belajar, kurang motivasi belajar, kurangnya fasilitas dan dukungan orangtua, atau karena kesalahan-kesalahan guru dalam cara mengajarnya sebagai akibat dari kurang memahami materi ajarnya, pendekatan yang harus digunakan atau kurang pemahaman terhadap karakteristik anakanaknya.

\section{Penutup}

Orangtua dalam keluarga, memegang peran penting, karena orangtua sebagai top manager yang menentukan berhasil dan tidaknya keluarga sakinah (bahagia/sejahtera). Peran orangtua terhadap pendidikan agama anak sangat besar sekali, terutama dalam mengarahkan fitroh Islam yang dibawa sejak lahir. Juga bahkan keluarga merupakan tempat pendidikan utama dan yang pertama bagi anak dan akan menjadi landasan hidup di kelak di kemudian hari, maka pendidikan agama harus dimulai sejak kecil, agar pemahaman keagamaan akan bisa melekat pada pribadi anak. Serta tertanam kebiasan-kebiasaan yang islami. Serta akan tumbuh subur dengan akhlaq yang dimulyakan. Itulah harapan orangtua muslim. 


\section{DAFTAR RUJUKAN}

Al-Ashqolani, A. I. H. Tanpa tahun. Bulughul Maroom. Tanpa kota: PT. Nur Asia.

Al-Istanbuli, M. M. 1989. Mendidik Anak Nakal. Bandung: Pustaka.

As-Suyuti, A. B. Tanpa tahun. Al-jami'ush shohir. Bandung: PT. Ma'arif.

Dinata, K. 2002. Bimbingan di Sekolah Dasar. Bandung: CV. Maulana.

Departemen Agama RI. 1982. Al-Qur'an Dasar Terjemahnya. Jakarta: Proyek Pengadaan Kitab Suci Al-Quran Departemen Agama.

Dirjen Pembinaan Kelembagaan Agama Islam. 1993. Pendidikan Agama Islam. Jakarta: Dirjen Pembinaan Kelembagaan Agama Islam dan PT. Dana Bhakti Wakaf.

Furqon. 2005. Konsep dan Aplikasi Bimbingan Konseling di Sekolah Dasar. Bandung: Pustaka Bani Quraisy.

Hasan, H. 1987. Mewujudkan Keluarga Sejahtera. Surabaya: CV Amin.

Nawasi, S. Tanpa tahun. Al-Adzkaar. Tanpa kota: PT. Nur Asia.

Sahli, M. 1990. Menuju Rumah Tangga Harmonis. Pekalongan: TB. Bahagia.

Shaleh, A., dan Suriadinate, S. 1981. Ilmu Keguruan Seri Pedagogik, Jakarta: Dharma Bhakti.

Yaljan, M. 1992. Potret Rumah Tangga Islam. Tanpa kota: Pustaka Mantiq. 